\title{
A Response to: Human Fall Detection Using Passive Infrared Sensors with Low Resolution: A Systematic Review [Letter]
}

\author{
I Ketut Andika Priastana $\mathbb{D}^{\prime}$, Juana Linda Simbolon ${ }^{2}$ \\ 'Universitas Triatma Mulya, Badung, Bali, Indonesia; ${ }^{2}$ Poltekkes Kemenkes Medan, Medan, North Sumatra, Indonesia \\ Correspondence: I Ketut Andika Priastana, Universitas Triatma Mulya, Badung, Bali, Indonesia, Tel +6283II42I3804, \\ Email iketutandikapriastana@gmail.com; Juana Linda Simbolon, Poltekkes Kemenkes Medan, Medan, North Sumatra, Indonesia, Tel +628I36232553I, \\ Email simbolonjuanalinda@gmail.com
}

\section{Dear editor}

We have read with great interest the paper entitled "Human Fall Detection Using Passive Infrared Sensors with Low Resolution: A Systematic Review" by Ben-Sadoun et al. ${ }^{1}$ This systematic review was designed and conducted according to the Preferred Reporting Items for Systematic reviews and Meta-Analyses (PRISMA, version 2020). ${ }^{2}$ The goal of this review was to identify studies that investigated the metrological qualities of passive infrared sensors with a very low resolution to identify falls or related conditions (eg, lying on the floor). ${ }^{1}$

However, two points need to be mentioned for the readers.

This protocol has not been registered in any international database of prospectively registered systematic reviews. It is recommended that the protocol be registered in the PROSPERO database to be reviewed by peers and to reduce unnecessary duplication of effort among researchers. If the review protocol has been registered, it must be indicated where it is accessible by providing the registration number and website address or using someone else's protocol. ${ }^{3}$ PROSPERO is an international database of prospectively registered systematic reviews in health and social affairs. ${ }^{4}$ The main features of the review protocol are recorded and maintained as a permanent record. Systematic reviews should be registered at the outset (ie, at the protocol stage) to help avoid unplanned duplication and to allow comparison of the reported review methods with those planned in the protocol. ${ }^{5}$

At the articles selection process stage, there are difficulties for readers to understand the PRISMA diagram shown. In the final stage of the PRISMA diagram, four articles were excluded because the four authors "duplicated" their study in two different journals, so there are 15 articles included in the analysis. However, Table 1 (Studies Characteristics Regarding Their Sensors Used, Experimental Procedures, Detection Methods, and Detection Performance) and Figure 2 (Publication dates of studies) still include 19 articles. The author should not include the four articles that have been excluded.

\section{Disclosure}

The authors report no conflicts of interest in this communication.

\section{References}

1. Ben-Sadoun G, Michel E, Annweiler C, Sacco G. Human fall detection using passive infrared sensors with low resolution: a systematic review. Clin Interv Aging. 2022;17:35-53. doi:10.2147/CIA.S329668

2. Page MJ, McKenzie JE, Bossuyt PM, et al. The PRISMA 2020 statement: an updated guideline for reporting systematic reviews. BMJ. 2021;372: n71. doi:10.1136/bmj.n71

3. Ebling Library University of Wisconsin-Madison-Health Science. Systematic reviews, a guide: home [Internet]; 2019.

4. Centre for Reviews and Dissemination University of York. About PROSPERO [Internet]; 2011.

5. PRISMA Group. Preferred reporting items for systematic reviews and meta-analyses (PRISMA) [Internet]; 2015. 
Dove Medical Press encourages responsible, free and frank academic debate. The content of the Clinical Interventions in Aging 'letters to the editor' section does not necessarily represent the views of Dove Medical Press, its officers, agents, employees, related entities or the Clinical Interventions in Aging editors. While all reasonable steps have been taken to confirm the content of each letter, Dove Medical Press accepts no liability in respect of the content of any letter, nor is it responsible for the content and accuracy of any letter to the editor.

Clinical Interventions in Aging

Dovepress

\section{Publish your work in this journal}

Clinical Interventions in Aging is an international, peer-reviewed journal focusing on evidence-based reports on the value or lack thereof of treatments intended to prevent or delay the onset of maladaptive correlates of aging in human beings. This journal is indexed on PubMed Central, MedLine, CAS, Scopus and the Elsevier Bibliographic databases. The manuscript management system is completely online and includes a very quick and fair peer-review system, which is all easy to use. Visit http://www.dovepress.com/testimonials.php to read real quotes from published authors.

Submit your manuscript here: https://www.dovepress.com/clinical-interventions-in-aging-journal 